\title{
Elemen Pengambilan Keputusan dalam Asuhan Keperawatan
}

\author{
Sri Raudatul Jannah
}

\section{$\underline{\text { Raudatuljannahsri@gmail.com }}$}

\section{Latar Belakang}

Konsep berpikir kritis merupakan elemen penting dalam pemberian asuhan keperawatan yang berkualitas. Elemen inti pendidikan keperawatan terdapat pada pemilihan dan penggunaan kegiatan pembelajaran yang mendukung konsep berpikir kritis yang diperlukan dalam aplikasi proses keperawatan serta mendukung lingkungan pembelajaran yang aktif (Kinchin, 2014).

Pengambilan keputusan klinis oleh perawat adalah proses kompleks yang berpotensi mempengaruhi kualitas layanan yang diberikan dan hasil pasien(Gillespie, 2010). Perawat merupakan unsur vital dalam sebuah Rumah Sakit karena perawat merupakan penjalin kontak pertama dan terlama dengan pasien khususnya pasien rawat inap, dengan tugas utama perawat adalah memberikan asuhan keperawatan dari pengkajian, penegakan diagnose keperawatan, intervensi, implementasi sampai dengan evaluasi (Potter \& Perry, 2009).

Pada pelayanan keperawatan, manajemen asuhan sangat diperlukan. Manajemen asuhan yang dilakukan seorang manajer keperawatan mempunyai pengaruh paling kuat dalam keberlangsungan keperawatan di pelayanan kesehatan (Marquis \& Huston, 2012). Proses manajemen dimulai dari perencanaan, pengorganisasian, ketenagaan, pengarahan, dan pengendalian terhadap faktor sumber daya manusia, keuangan, material, metode, dan fasilitas (Marquis \& Huston, 2015).

Perawat dalam mengidentifikasi dan merespons pasien yang memburuk terkadang membuat keputusan secara otonom, salah menafsirkan bukti, tanggapan yang terkondisi dan tidak melihat isyarat (Johansen \& Brien, 2015). Keputusan klinis yang dibuat perawat harus didukung dengan data yang akurat serta lengkap dan sistim yang baik agar dapat menjawab kebutuhan pasien secara tepat. Sistim pendukung keputusan klinis ( CDSS ) yang direncanakan dengan baik dan dimasukkan ke dalam layanan kesehatan akan menciptakan layanan yang berkualitas dan meningkatkan efektivitas serta mengurangi biaya perawatan (Parsania et al., 2017)

Keyword : Elemen Pengambilan Keputusan, Asuhan Keperawatan 


\section{Metode}

Metode yang digunakan pada penelitian ini adalah metode kualitatif yaitu penelitian yang digunakan untuk meneliti pada kondisi objek alamiah, dimana peneliti merupakan instrumen kunci (Sugiyono, 2005). Serta dengan menggunakan analisa dari berbagai referensi seperti buku atau jurnal dan berfokus pada metode pembelajaran mengenai peran perawat tentang insiden yang terjadi dalam keselamatan paisen di rumah sakit. Referensi adalah sesuatu yang dipakai dalam pemerian informasi untuk memperkuat pernyataan dengan tegas, atau sering disebut juga dengan "rujukan". Sumber materi referensi ialah tempat materi itu ditemukan.

Dalam pengambilan data yang dilakukan secara menganalisa data dari beberapa jurnal yang ada serta mendapatkan referensi gabungan yang di tuangkan dalam jurnal ini. Sumber yang digunkan adalah sumber yang terbit dari mulai tahun 2012 hingga sekarang.

\section{Hasil}

Hasil yang dapat diambil dalam menentukan pengambilan keputusan yang tepat yaitu menggunakan suatu pendekatan yang sistematis terhadap hakekat suatu masalah dengan pengumpulan fakta-fakta dan data. Dalam menentukan alternatif yang matang untuk mengambil suatu tindakan yang tepat didasarkan pada kriteria tertentu atas dua atau lebih alternatif yang sesuai (George R. Terry, 2019).

Proses pengambilan keputusan dalam praktik klinik keperawatan dipahami sebagai serangkaian keputusan yang dibuat oleh perawat dalam interaksinya dengan pasien mengenai jenis pengamatan yang akan dilakukan dalam situasi yang di alami klien (pengkajian keperawatan), perumusan diagnosa keperawatan, rencana tindakan keperawatan yang harus diambil, tindakan keperawatan yang akan diambil serta evaluasi (Dianan Catarina. 2009, Jan Florin. 2007, Mehee, 2014).

Berpikir kritis digambarkan sebagai "sebuah proses, tujuan untuk membuat keputusan yang masuk akal tentang apa yang harus percaya dan apa yang harus dilakukan". Pengambilan keputusan klinis adalah sebuah proses yang melibatkan kedua penalaran diagnostik dan penilaian klinis. Tindakan ini diarahkan sebagai proses refleksi dari perawat maupun pasien (Jan Florin, 2007).

Pengambilan keputusan sangat penting keberadaannya dalam asuhan maupun dalam manajemen keperawatan. Pengambilan keputusan merupakan suatu proses yang mencakup 
semua penilaian kegiatan yang diperlukan guna membuktikan dan meperlihatkan pilihan terbaik dalam menyelesaiakan suatu masalah tertentu. setiap keputusan adalah akibat dari sebuah proses dinamis yang dipengaruhi oleh banyak kekuatan, pengambilan keputusana bukan merupakan prosedur yang tetap akan tetapi sebuah proses yang beruntun. pengambilan keputusan adalah proses yang melibatkan pendekatan sistemik yang harus diadaptasikan dengan lingkungan dalam suatu ketentuan.

Pengambilan keputusan keperawatan dilakukan pada semua tahap proses keperawatan. Sehingga seorang perawat harus mampu berpikir ktitis, berkomunikasi dengan baik sebagai suatu elemen penting dalam pengaambilan keputusan klinis, sehingga terjadi pembelajaran berkelanjutan bagi pasien agar dapat meningkatkan tingkat kemandirian pada pasien.

Pada pelayanan keperawatan, manajemen asuhan sangat diperlukan. Manajemen asuhan yang dilakukan seorang manajer keperawatan mempunyai pengaruh paling kuat dalam keberlangsungan keperawatan di pelayanan kesehatan (Marquis \& Huston, 2012).

\section{Pembahasan}

Pengambilan keputusan sangat penting keberadaannya dalam asuhan maupun dalam manajemen keperawatan. Pengambilan keputusan merupakan suatu proses yang mencakup semua penilaian kegiatan yang diperlukan guna membuktikan dan meperlihatkan pilihan terbaik dalam menyelesaiakan suatu masalah tertentu. setiap keputusan adalah akibat dari sebuah proses dinamis yang dipengaruhi oleh banyak kekuatan, pengambilan keputusana bukan merupakan prosedur yang tetap akan tetapi sebuah proses yang beruntun. pengambilan keputusan adalah proses yang melibatkan pendekatan sistemik yang harus diadaptasikan dengan lingkungan.

Perawat dengan kemampuan berfikir kritis yang baik akan menyadari perannya dan identitas diri dalam kaitannya dengan hal-hal, peristiwa dan orang lain. Berfikir kritis penting dilakukan sebelum mengambil keputusan dalam asuhan keperawatan karena berfikir kritis dalam keperawatan merupakan keterampilan berfikir perawat untuk menguji berbagai alasan secara rasional sebelum mengambil keputusan dalam asuhan keperawatan sehingga asuhan keperawatan yang diberikan akan maksimal dan jauh lebih baik.

Asuhan keperawatan merupakan bagian dari suatu sistem pelayanan yang terintegrasi dengan para profesional di bidang pelayanan kesehatan dan tingkat pelayanan yang akan membangun suatu kontinuitas pelayanan. Maksud dan tujuannya adalah menyelaraskan 
kebutuhan asuhan pasien dengan pelayanan yang tersedia di rumah sakit, mengoordinasikan pelayanan, kemudian merencanakan pemulangan dan tindakan selanjutnya.

Kode etik menjadi dasar yang sangat penting bagi perawat dalam membina hubungan yang baik dengan semua pihak pada saat memberikan pelayanan kesehatan. Jika hubungan perawat dengan pasien dan pihak lainnya terjalin dengan baik, maka kesembuhan dan kepuasan pasien menjadi lebih mudah dicapai. Perawat yang setiap saat berada di sisi pasien seharusnya memberikan asuhan keperawatan dengan baik dan menerapkan kode etik keperawatan selama melakukan pelayanan kesehatan. Namun kenyataannya masih banyak ditemukan kasus pelanggaran kode etik pada saat pelaksanaan pelayanan keperawatan. Pasien sering kali merasa tidak puas atas pelayanan kesehatan yang diberikan. Pasien juga merasa kebutuhannya tidak terpenuhi dengan baik oleh perawat (Nursalam, 2014)

Pemberian pelayanan keperawatan secara profesional perawat diharapkan mampu menyelesaikan tugasnya dalam memberikan asuhan keperawatan untuk meningkatkan derajat pasien menuju ke arah kesehatan yang optimal.

Berpikir kritis penting dilakukan oleh perawat sebelum mengambil keputusan dalam asuhan keperawatan.Asuhan keperawatan merupakan satu metode ilmiah dalam penyelesaian masalah klien. Kemampuan perawat mengidentifikasi masalah klien dan memilih solusi intervensi yang tepat tidak lepas dari kemampuan perawat berpikir kritis, yaitu kemampuan perawat menggali alasan berdasarkan evidence base dari setiap problem dan solusi yang teridentifikasi. Kemampuan berpikir kritis dan disposisinya dapat digunakan ketika menyelesaikan masalah keperawatan (Zori \& Morrison, 2009).

Sesuai dengan standar disiplin profesi pendokumentasian dan pelaksanaan tersebut harus sesuai dengan standar yang telah ditetapkan yaitu harus memenuhi standar sebagai berikut:

1. Pengkajian Keperawatan dilakukan berdasarkan standart pengkajian yang digunakan dalam rumah sakit yang bersangkutan dan dilakukan dokumentasi sesuai dengan standart yang ada.

2. Diagnosa adalah sebuah keputusan dan sekaligus sebagai hipotesis terhadap masalah yang dihadapi oleh pasien selama dilakukan perawatan dirumah sakit. Data pasien harus divalidasi /reasesment setiap hari, sehingga diagnosa menyesuaikan data yang ditemukan pada hari itu karena diagnosa keperawatan adalah respon dimana kemungkinan respon setiap hari berubah. Jika respon pasien berubah maka diagnosa keperawatanpun akan berubah pula. 
3. Perencanaan merupakan suatu langkah sitematis untuk mengatasi masalah keperawatan sesuai dengan tujuan yang diharapkan. Jika diagnosa berubah maka intervensi harus mengikuti diagnosa yang muncul dan terdokumentasi.

4. Implementasi Keperawatan merupakan tindakan yang dilakukan oleh seoarang perawat berdasarkan intervensi/ rencana keperawatan. Dalam pelaksanaannya harus ada Standar Prosedur Operasional (SPO) atau panduan dalam melakukan implementasi.

5. Evaluasi adalah validasi terus menerus menerus terhadap pencapaian tujuan keperawatan berdasarkan diagnosa yang di ambil.

Pemberian asuhan keperawatan harus memeperhatikan klien dengan memberikan penghargaan individu meliputi preferensi, keperluan, nilai-nilai, dan memastikan bahwa semua pengambilan keputusan klinik telah mempertimbangkan dari semua nilai-nilai yang diingini pasien (Comite if quality of health institute of medicine 2001).

Pelaksanaan proses keperawatan ini dibutuhkan kemampuan perawat dalam mengambil keputusan klinis dan tanpa mengesampingkan nilai disiplin etik dan bioetik keperawatan. Karena dalam proses ini perawat harus melibatkan pasien karena pasien juga ingin ikut terlibat dalam proses keperawatan yang akan dia terima selama melakukan asuhan keperawatan.

Perawat harus mampu mengidentifikasi masalah pasien dan memilih solusi intervensi yang tepat, karena perawat akan menghadapi bermacam-macam situasi klinis yang berhubungan dengan pasien dimana hal ini tak lepas dari kemampuan perawat dalam berfikir kritis, karena dengan berfikir secara kritis perawat dapat mengambil keputusan secara sistematis dan tepat dalam setiap tahapan asuhan keperawatan yang dilakukan.

Hubungan perawat-klien adalah suatu hubungan interpersonal yang profesional dan terapeutik dengan tujuan memenuhi kebutuhan klien. Hubungan profesional perawat dan klien didasarkan pada pemahaman bahwa klien adalah orang yang paling tepat untuk membuat keputusan. Peran utama tim kesehatan adalah memfasilitasi dan memberdayakan potensi internal klien. Dengan demikian, hubungan yang terjadi haruslah menguntungkan klien dan tidak memiliki efek yang negatif bagi klien. Dalam pengambilan keputusan seorang perawat harus berlandaskan etika praktik keperawatan yang berdasarkan pada pemikiran kritis dan reflektif mengenai tanggung jawab dan kewajiban seorang perawat terhadap klien (Jan Florin, 2007 dan Fakultas Ilmu Keperawatan Universitas Padjajaran, 2013). 
Dokumentasi keperawatan mempunyai makna penting dalam aspek hukum, kualitas pelayanan, komunikasi, pendidikan, penelitian, dan akreditasi. Berkaitan dengan perlindungan hukum, dokumentasi asuhan keperawatan dapat memberi bukti yang berharga tentang kondisi pasien dan pengobatannya dan dapat bersifat kritis dalam menentukan standar perawatan apakah telah dipenuhi atau tidak (Nursalam, 2008).

Pada pelayanan keperawatan, manajemen asuhan sangat diperlukan. Manajemen asuhan yang dilakukan seorang manajer keperawatan mempunyai pengaruh paling kuat dalam keberlangsungan keperawatan di pelayanan kesehatan (Marquis \& Huston, 2012). Proses manajemen dimulai dari perencanaan, pengorganisasian, ketenagaan, pengarahan, dan pengendalian terhadap faktor sumber daya manusia, keuangan, material, metode, dan fasilitas (Marquis \& Huston, 2015).

\section{Penutup}

Dalam membuat keputusan harus dikenali dan didefinisikan adanya masalah atau situasi dan menganalisis pilihan yang ada, mencocokan tiap pilihan konsekuensi dari keputusan yang diambil, dan membuat keputusan akhir. Serta dalam mengambil suatu keputusan seorang perawat juga harus berfikir kritis dalam menaggapi masalah yang harus diselesaikan dan dapat mencapai kesimpulan yang memuaskan.

Perawat harus mampu mengidentifikasi masalah pasien dan memilih solusi intervensi yang tepat, karena perawat akan menghadapi bermacam-macam situasi klinis yang berhubungan dengan pasien dimana hal ini tak lepas dari kemampuan perawat dalam berfikir kritis dan harud dapat membuat atau membina hubungan yang baik dengan pasien agar dapat mencapai tujuan dari keputusan yang diambil oleh perawat.

\section{Daftar Pustaka}

1. Bambang Sudono DS Dhani Setya A Rif Atiningtyas H. (2017). GAMBARAN KEMAMPUAN BERPIKIR KRITIS PERAWAT PRIMER DALAM PELAKSANAAN ASUHAN KEPERAWATAN DI RUMAH SAKIT ISLAM SURAKARTA. Jurnal Ilmu Keperawatan Indoensia, 10(1), 79-106.

2. Daniel Dady, D., Kadek, A. E., \& Rini, R. (2020). SISTIM PENDUKUNG DALAM PEMBUATAN KEPUTUSAN KLINIS PERAWAT DI RUANG RAWAT INAP : LITERATUR REVIEW. Jurnal Ilmu Kesehatan, 8(2), 173-181. 
3. Deniati, k., Ria, A., \& Tini, S. (2018). PENGARUH BERFIKIR KRITIS TERHADAP KEMAMPUAN PERAWAT PELAKSANA DALAM MELAKUKAN ASUHAN KEPERAWATAN DI RUMAH SAKIT HERMINA BEKASI TAHUN 2016. Jurnal Kesehatan Holistik (The Journal of Holistic Healthcare), 12(1), 21-25.

4. Hafifah, I., \& Noor, Fithriyah. (2018). PENGALAMAN KELUARGA DALAM PENGAMBILAN KEPUTUSAN PADA PASIEN KRITIS DI RUANG INTENSIVE CARE UNIT (ICU) RSUD ULIN BANJARMASIN. Dunia Keperawatan, 6(1), 1118.

5. Hastuti, W., \& Widiyaningsih. (2017). APLIKASI CONCEPT MAPPING DALAM PEMBERIAN ASUHAN KEPERAWATAN DI STASE MATERNITAS. Jurnal Keperawatan dan Pemikiran Ilmiah, 3(3), 19-26.

6. Rahayu, C. D., \& Sri. M. (2020). PENGAMBILAN KEPUTUSAN KLINIS PERAWAT. Jurnal Ilmiah Kesehatan, 10(1), 1-11.

7. Sugiyati, S. (2015). HUBUNGAN PENGETAHUAN PERAWAT DALAM DOKUMENTASI KEPERAWATAN DENGAN PELAKSANAANNYA DI RAWAT INAP RSI KENDAL. Jurnal Keperawatan, 8(2), 109 - 125.

8. Simamora, R. H. (2005). Hubungan Persepsi Perawat Pelaksana Terhadap Penerapan Fungsi Pengorganisasian Yang Dilakukan Oleh Kepala Ruangan Dengan Kinerjanya Diruang Rawat Inap RSUD Koja Jakarta Utara (Doctoral dissertation, Tesis FIK UI, Tidak dipublikasikan).

9. Simamora, R. H. (2019). Menjadi perawat yang: CIH'HUY. Surakarta: Kekata Publisher.

10. Imran Pashar, I., \& Luky, D. (2020). Pengaruh Empowerment Terhadap Pengambilan Keputusan Perawat: Kajian Literature Review. JOURNAL OF HOLISTIC NURSING SCIENCE, 7(2), 124-132.

11. Tetty, V., \& Aprilia, N. (2017). PENGEMBANGAN INSTRUMEN PENILAIAN KINERJA ASUHAN KEPERAWATAN BERBASIS WEB DI RUANG RAWAT INAP. Mahakam Nursing Journal, 2(2), 62-73.

12. Zendrato, M. V., \& Rr. Tutik. S. H. (2017). OPTIMALISASI PENGELOLAAN ASUHAN KEPERAWATAN DI INSTALASI RAWAT JALAN RUMAH SAKIT X. JPPNI, 2(2), 1-15. 